\title{
Epstein-Barr virus in oral mucosa from human immunodeficiency virus positive patients
}

\author{
Larissa Santos ${ }^{1}$, Kátia Azevedo ${ }^{2}$, Licinio Sillva ${ }^{3}$, Ledy Oliveira ${ }^{1}$ \\ ${ }^{1}$ Department of Microbiology and Parasitology, Fluminense Federal University, Niterói, RJ, Brazil. \\ ${ }^{2}$ College of Medicine, Fluminense Federal University, Niterói, RJ, Brazil. \\ ${ }^{3}$ Department of Statistics, Fluminense Federal University, Niterói, RJ, Brazil.
}

Study conducted at the Department of Microbiology and Parasitology, Fluminense Federal University, Niterói, RJ, Brazil

Article received: $07 / 22 / 13$ Accepted for publication: 10/06/13

*Correspondence: Departamento de Microbiologia e Parasitologia Universidade Federal Fluminense Address: Rua Prof. Ernani Melo, 101, Niterói, RJ - Brazil ZIP Code: $24210-130$ Phone: +55 21 2629-2430 Fax: +55 $212629-2433$ mipledy@centroin.com.br http://dx.doi.org/10.1590/1806-9282.60.03.016 Conflict of interest: none

\section{SUMmaRY}

Objective: the detection rate of Epstein-Barr virus (EBV) is higher in people living with human immunodeficiency virus (HIV). In an attempt to contribute to our epidemiological understanding of this coinfection and to investigate the activity of EBV in normal oral mucosa, we performed a cross-sectional study with HIV-positive patients.

Methods: oral smears from $145 \mathrm{HIV}$-positive patients were collected between March 2010 and March 2011. Nested polymerase chain reaction (PCR) and reverse transcriptase-PCR (RT-PCR) were used to genotype EBV and to detect EBNA-2 expression, respectively.

Results: EBV DNA was detected in $48.3 \%$ of the study participants, of whom $32.85 \%$ were EBV- 1 and $45.71 \%$ were EBV-2 carriers. Additionally, $14.28 \%$ were coinfected with both types. EBNA-2 mRNA was expressed in $45.7 \%$ of the EBV-positive samples, including $20.0 \%$ with EBV-1 only, 20.0\% with EBV-2 only and $1.4 \%$ with both genotypes. Immune status affected the overall EBV infection, and EBV-2 positivity was significantly correlated with sexual lifestyle of the participants. EBV co-infection with both viral types was dependent upon HIV viral load and the activity of the EBNA-2 gene.

Conclusion: we report a high prevalence of active EBV in the oral mucosa of asymptomatic HIV-seropositive individuals. This study addresses the need for monitoring and treatment of HIV-infected patients with EBV reactivation.

Key words: Epstein-Barr virus; HIV; genotypes; oral mucosa.

\section{INTRODUCTION}

Epstein-Barr virus (EBV), a member of the Herpes viridae family, is a common virus worldwide. Human EBV infections are often asymptomatic and persistent. Primary infection occurs in B lymphocytes of the oropharyngeal mucosa where lytic and latent infections take place. Although EBV replication in oral epithelial cells is an infrequent event, the virus is usually shed in and transmitted by saliva. ${ }^{1} \mathrm{EBV}$ interacts with the host by infecting B lymphocytes and inducing the proliferation of infected cells. Following a proliferative phase, EBV enters a latent phase and can be reactivated, giving rise to the production of infectious progeny that can be transmitted to other individuals. $^{2}$

EBV strains are classified as type 1 or 2 according to variations in the regions encoding $\mathrm{EBV}$ nuclear antigen 2 (EBNA-2), 3A (EBNA-3A), 3B (EBNA-3B) and 3C (EB-
NA-3C). ${ }^{3}$ EBV type 1 is prevalent in most of populations studied. ${ }^{4,5}$ However, other studies have revealed that in specific geographic areas, the prevalence of EBV type 1 is similar to the prevalence of EBV type $2 .{ }^{6}$

Risk factors for EBV infection and its genotypes have not been fully investigated. EBV seropositivity studies suggest an association with socioeconomic factors, specifically among children of low socioeconomic status. ${ }^{7}$ In adults, oral transmission can be masked by other modes of transmission, such as sexual contact. ${ }^{8}$ Epidemiologically, EBV type 2 strains are more frequently associated with HIV-positive individuals and homosexual HIV-positive males as well as with sexual contact. ${ }^{9-11}$

Studies have shown a higher prevalence of EBV among HIV-seropositive individuals than the general population (Table 1). 
TABLE 1 EBV infection survey in normal oral mucosa in HIV-positive and HIV-negative patients

\begin{tabular}{l|l|l|l|l} 
Reference & Location & Number of patients & EBV $\%$ & HIV status \\
\hline Amornthatree et al., $2011^{12}$ & Thailand & 49 & 80 & + \\
\hline Robaina et al., $2008^{5}$ & Brazil & 27 & 51 & + \\
\hline Ammatuna et al., $2001^{13}$ & Italy & 57 & 42.1 & + \\
\hline Mao \& Smith, $1993^{14}$ & UK & 60 & 25 & - \\
\hline Kunimoto et al.,1992 & Japan & 91 & 23 & - \\
\hline Scully et al., $1998^{9}$ & UK & - & 20 & - \\
\hline Cruz et al., $1997^{15}$ & Netherlands & 12 & 8.3 & - \\
\hline Sand et al., $2002^{16}$ & Sweden & 67 & 7.3 & - \\
\hline
\end{tabular}

EBV carriers in the HIV-seropositive group merit concern due to the pathogenic and even malignant potential of the virus. Although in most cases, EBV infection is linked to benign diseases, the virus can produce malignances. In most individuals, a lifelong chronic infection with $\mathrm{EBV}$ is free from complications due to suppression from normal immune systems. ${ }^{17}$ However, patients with acquired immunosuppression are at a high risk for developing both benign and malignant conditions. ${ }^{18}$

All latent viral genes express proteins to activate and maintain the proliferation of B cells (latency III program). ${ }^{19}$ EBNA-2 is one of the first viral genes expressed after infection and is essential for the immortalization of B cells and the establishment of latent infection. ${ }^{1,20}$ The expression of EBNA-2 is associated with the pathogenesis of oral hairy leukoplakia, a benign AIDS-related disease. ${ }^{21}$ The hairy leukoplakia (HLP) lesion is a unique example of a permissive infection with EBV in the tongue epithelium. Among other gene products, the EBNA-2 protein has been shown to activate the expression of the EBV receptor CD21. ${ }^{22}$ EBNA-2 mRNA is also associated with the symptoms of apical periodontitis. ${ }^{23}$ The broad spectrum of EBNA-2 functions involves virus-host interactions, including cell signaling molecules, adapters, genes involved in cell cycle regulation, and leukocyte chemotaxins. ${ }^{24}$

In light of the potential damage Epstein-Barr virus can cause in those living with HIV, we describe the results of screening for EBV and its subtypes, variables associated with EBV-HIV coinfection and EBNA-2 expression in an HIV-infected population.

\section{Methods}

Between 2009 and 2010, oral cavity scrapes were taken from 150 HIV-infected adults who were representative of the HIV-positive population of the state of Rio de Janeiro. The size of the sample was determined considering lo- wer EBV expected frequencies in this population, according to specialized reference. ${ }^{4}$

Participants were invited to enroll in the study during routine standard-of-care visits to 450 patients registered in the outpatient HIV clinic of the Infectious Diseases Service of the Antonio Pedro Teaching Hospital, in Niterói, Rio de Janeiro, Brazil. Of these individuals, 145 were asymptomatic, and the remaining five patients, who exhibited oral lesions, were excluded from the study. Samples were collected by scraping the oral mucosa after clinical examination. Demographic, behavioral and HIV infection-related data were obtained via a structured questionnaire. The Ethics Committee of the College of Medicine at UFF approved the protocols for sample collection and informed consent.

CD4 counts were determined by Flow Cytometric Immunophenotyping using standard protocols. Plasma HIV1 RNA levels were measured in virology quality assurance-certified laboratories according to the same program with the Chiron Versant HIV-1 RNA 3.0 Assay (Bayer Corporation, Emeryville, California, USA) in accordance with the manufacturer's instructions; the lower threshold of detection was 50 copies $/ \mathrm{mL}^{25}$ All assays were performed in a laboratory participating in the National STD and AIDS Program.

DNA was extracted from samples using either the phenol-chloroform method or a commercial assay kit (Invisorb, Uniscience). EBV detection and typing were performed using generic and nested PCR, respectively. For EBV DNA detection, the primer pair E2P1: 5'-AGGGATGCCTGGACACAAGA-3', B95.8 coordinates 1813-1833, and E2P2: 5'-TGGTGCTGCTGGTGGTGGCAAT-3', B95 coordinates 2409-2366, which amplify a 596 bp DNA sequence specific to the EBNA-2 gene, were used. ${ }^{26,27} \mathrm{Am}$ plification was performed in a $50 \mu \mathrm{L}$ reaction mixture (1x PCR buffer, $200 \mathrm{mM}$ dNTPs, $1.5 \mathrm{mM} \mathrm{MgCl}_{2}, 50 \mathrm{pmol}$ 
of each primer, $0.25 \mathrm{U}$ of Taq polymerase and $5 \mu \mathrm{L}$ of sample) with 40 cycles of amplification. Each cycle included a denaturing step at $94^{\circ} \mathrm{C}$ for 30 seconds, an annealing step at $58^{\circ} \mathrm{C}$ for 30 seconds, and a chain elongation step at $72^{\circ} \mathrm{C}$ for 60 seconds using a thermal cycler (Veriti, Applied Biosystems). The b-actin gene was amplified as an internal positive control using $0.1 \mathrm{pmol}$ of each primer. PCR products were analyzed on $1.5 \%$ agarose gel with ethidium bromide staining for the visualization of DNA under ultraviolet light.

To type EBV-positive samples, nested PCR was performed by internal amplification of $2 \mu \mathrm{L}$ of the primary PCR products. The Ap1/Ap2 and Bp1/Bp2 primer pairs (Life Technologies, S. Paulo, Brazil) amplified $497 \mathrm{bp}$ and 150 bp products from EBV-1 and EBV-2, respectively. The inner primers used were as follows: Ap1: 5'-TCTTGA TAG GGATCCGCTAGG ATA-3', B95.8 coordinates 1843-1856; Ap2: 5'-ACCGTGGTTCTGGAC TAT CTG GAT C-3', B95.8 coordinates 2338-2314, to detect the $497 \mathrm{bp}$ fragment; BP1: 5'-CAT GGT AGCCTTAGGACA TA-3', B95.8 coordinates 2085-2104; and BP2: 5'-AGA CTTAGTTGATGCCCT AG3', coordinates $2234-2215$ to detect the $150 \mathrm{bp}$ fragment. ${ }^{26,27}$ Nested PCR was performed with 25 cycles consisting of the following steps: $94^{\circ} \mathrm{C}$ for 30 seconds, $58^{\circ} \mathrm{C}$ for 30 seconds, and $72^{\circ} \mathrm{C}$ for 45 seconds, with a final elongation step at $72{ }^{\circ} \mathrm{C} .{ }^{26}$ Positive and negative controls were also included. To prevent false-positive results, in addition to the standard controls, a sample containing extracted non-EBV DNA was amplified with the EBV-specific primers. Nested PCR products were analyzed by the same methods as the primary generic PCR products.

RNA for reverse transcriptase polymerase chain reaction (RT-PCR) was extracted with Trizol ${ }^{\circledR}$ Reagent (Invitrogen, S. Paulo, Brazil). The resulting RNA was quantified on Qubit ${ }^{\circledR}$ 2.0 Fluorometer (Invitrogen). For cDNA synthesis, 2 pmol of each of the specific primers described above (EP1/EP2, expected size 596 bp, exon-flanking primers) was added to $10 \mu \mathrm{L}$ of RNA followed by heating for $5 \mathrm{~min}$ at $65^{\circ} \mathrm{C}$. Reverse transcription was performed using SuperScript ${ }^{\mathrm{TM}}$ III Reverse Transcriptase (Invitrogen, S. Paulo, Brazil) for 1 hour at $55^{\circ} \mathrm{C}$ followed by a 15 minutes incubation at $70^{\circ} \mathrm{C}$. The resulting cDNA was used as a template for generic and nested PCR using the EBV-specific primers described above. Controls were performed using RNA-free water.

A databank was generated and analyzed using the SPSS version 17 statistical package. To identify associations between possible risk factors and the presence of EBV and EBV-1 and EBV-2 separately, odds ratios (OR) with 95\% confidence intervals $(95 \% \mathrm{CI})$ were calculated. Relationships between the surveyed variables and active EBV infection were identified by univariate analysis. Multivariate analyses were conducted using logistic binary regression models between all variables and EBV infection.

\section{Results}

A total of 145 HIV-seropositive patients without clinical oral lesions, of whom 77 (53.1\%) were female and 68 (46.9\%) were male and ranging from 19 to 75 years of age ( mean $=41.38$, median $=41, \mathrm{SD}=10.35$ years , were recruited for the study. Among the self-referred ethnic groups, white (66.2\%) was the most prevalent category, and most of the subjects reported education at or above high school level (57.2\%). Nearly half of the study population claimed to have a stable sexual partner (54.5\%), $73.8 \%$ were currently non-smokers, and $56.6 \%$ were ex-smokers. With respect to HIV infection status, $61.4 \%$ of patients had an undetectable HIV viral load, $75.9 \%$ of participants reported being diagnosed more than 4 four years prior, and $85.5 \%$ were undergoing antiviral therapy. At the time of our study, $12.4 \%$ of patients had a CD $4+$ cell count below $200 \mathrm{CD} 4+$ cells/mL; 35.2\% had 201-500 CD4+ cells $/ \mathrm{mL}$; and $52.4 \%$ had more than $500 \mathrm{CD} 4+$ cells $/ \mathrm{mL}$.

In our study, EBV DNA was detected in $48.3 \%$ of the samples, 23 (32.85\%) of which only contained EBV type $1,32(45.71 \%)$ only contained EBV type 2, and 10 (14.28\%) contained both types. Among the EBV-positive samples, five $(7.14 \%)$ could not be identified and were referred to as unclassified types because the first PCR run was positive and the second was negative. Of the total, $35(24.1 \%)$ samples were positive by the first PCR assay with general EBV DNA primers. The determination of positivity for the remaining samples was only possible through nested PCR with type-specific primers (Table 2).

TABLE 2 Overall distribution of active EBV and subtypes in oral smears from HIV-infected patients from the Antonio Pedro Teaching Hospital, in Niterói, Rio de Janeiro, Brazil (2010)

\begin{tabular}{l|l|l|l|l|l} 
Patient & EBV $(\%)^{1}$ & EBV-1 $(\%)^{2}$ & EBV-2 $(\%)^{2}$ & EBV-1/EBV-2 $^{2}$ & Unclassified $^{3}(\%)$ \\
\hline Positive & $70(48.3)$ & $23(32.8)$ & $32(45.7)$ & $10(14.28)$ & $5(7.14)$ \\
\hline Negative & $75(51.7)$ & $47(67.2)$ & $38(54.3)$ & $60(85.72)$ & $65(92.86)$ \\
\hline
\end{tabular}

${ }^{1} \mathrm{~N}=145 ;{ }^{2} \mathrm{~N}=70 ;{ }^{3}$ Detection only by generic PC. 
EBNA-2 mRNA was detected in 32 (45.7\%) positive samples, of which, $14(20 \%)$ were typed only as EBV-1 and the other $14(20 \%)$ were typed only as EBV-2. Of the remaining smears, $1.4 \%$ was positive for EBNA-2 mRNA in samples with both types of EBV, and $4.3 \%$ were unclassified.

A univariate analysis of individuals with detectable EBV DNA and several variables revealed that a CD4+ cell count lower than 500 cells $/ \mathrm{mL}$ was the only factor that affected the overall infection. However, when we crossed the same variables with the EBV types separately, we verified that EBV type 1 was affected by $\mathrm{CD} 4$ counts below 200 cells $/ \mathrm{mm}^{3}(\mathrm{OR}=4.41$ [95\% CI: 1.49-13.03], $\mathrm{p}=0.012)$ and that patients who did not have a stable sexual partner were significantly more likely to be positive for EBV type 2 than those with a stable partner $(\mathrm{OR}=2.88[95 \%$ CI: 1.26-6.55], $\mathrm{p}=0.017)$. Moreover, detectable HIV viral load was associated with coinfection with EBV types 1 and $2(\mathrm{OR}=6.62$ [95\% CI: 1.32-33.16], $\mathrm{p}=0.025)$. The activity of the EBNA-2 gene was also strongly associated with detectable viral load (OR $=5.67$ [95\% CI: 1.99-16.13], $\mathrm{p}=0.002)$. No demographic associations were found.

Adjusted ORs were estimated for all risk factors with less than a $10 \%$ significance level in the univariate analysis. CD4+ counts lower than 500 cells $/ \mathrm{mm}^{3}$ remained a significant variable relative to EBV positivity in HIV-positive individuals. Irrespective of the patient's immune status, active EBV-2 infection was associated with sexual lifestyle (Table 3).

\section{Discussion}

Here, we investigated several aspects of EBV in the oral epithelial tissues of a random sampling of patients without mouth lesions who were attending an outpatient HIV care service. Oral brushing proved to be an efficient method for collecting epithelial cells. ${ }^{13}$ A PCR assay following nested PCR (with type-specific primers) increased the detection of EBV from 35 to 70 EBV-infected persons, thereby demonstrating a $100 \%$ improvement by this method.

As shown in Table 1, our results are consistent with previous research performed with similar study populations, which collectively demonstrate that EBV infection of the oral cavity is detected at a higher rate among HIV-infected individuals than among HIV-seronegative individuals. However, these data do not hold true for all herpes virus family members. Carvalho et al., ${ }^{28}$ demonstrated a strong correlation between the presence of EBV and $\mathrm{CMV}$ in HIV-seropositive individuals but not between the presence of herpes simplex virus (HSV-1) or human herpes virus type 8 (HHV-8).

The detection of replicating EBV DNA in the oral mucosa of HIV-positive individuals may indicate virus reactivation. After primary infection, EBV can induce replicative and latent infection in lymphocytes. The main site of viral persistence is within latently infected lymphocytes, although infectious virus is also released into the saliva from productively infected cells in the oropharynx. The virus persists for the lifetime of the host in balance

TABLE 3 Univariate analysis and adjusted ORs for identifying independent variables in active EBV infection among

HIV-positive patients

\begin{tabular}{|c|c|c|c|c|}
\hline Variable & Univariate analysis & & Adjusted OR & \\
\hline & EBV & & & \\
\hline CD4+ cell count $\leq 500$ & $3(1.52-5.9)$ & 0.002 & $2.54(1.26-5.1)$ & 0.009 \\
\hline \multirow[t]{2}{*}{ Detectable HIV viral load } & $1.98(0.99-3.94)$ & 0.075 & $1.62(0.79-3.34)$ & 0.185 \\
\hline & EBV-1 & & & \\
\hline \multirow[t]{2}{*}{ CD4+ cell count $\leq 200$} & $4.41(1.49-13.03)$ & 0.012 & & \\
\hline & EBV-2 & & & \\
\hline CD4+ cell count $\leq 500$ & $2.17(0.97-4.87)$ & 0.087 & $2.03(0.89-4.62)$ & 0.092 \\
\hline \multirow[t]{2}{*}{ Non-stable sexual partner } & $2.88(1.26-6.55)$ & 0.017 & $2.74(1.19-6.29)$ & 0.017 \\
\hline & EBV1/EBV2 & & & \\
\hline \multirow[t]{2}{*}{ Detectable HIV viral load } & $6.62(1.32-33.16)$ & 0.025 & & \\
\hline & mRNA & & & \\
\hline Detectable HIV viral load & $5.70(1.99-16.13)$ & 0.002 & & \\
\hline
\end{tabular}


with the immune system by latently infecting B lymphocytes and replicating in and shedding from the oral mucosa. In the oral mucosa, B cells are stimulated to differentiate after exposure to foreign antigens. ${ }^{29}$ Latency, cell proliferation and virus production occur simultaneously at different sites that are linked in dynamic equilibrium. ${ }^{2}$ In healthy individuals, systemic reactivation is kept in check by the immune system. ${ }^{29,30}$ However, asymptomatic EBV reactivation periodically occurs in oral mucosa-associated lymphoid tissues. ${ }^{31}$ According to Yao et al., ${ }^{32}$ chronic, usually low-grade virus replication occurs in the oro/nasopharynx from EBV carriers. In immunodeficient individuals, lytic replication can also be regularly activated. In this population, EBV replication can occur, albeit infrequently, in the epithelial cells of the tongue. ${ }^{33}$

In our study population, HIV status may modulate $\mathrm{EBV}$ infection. Due to the age of most of the participants, it is likely that they were infected with EBV prior to HIV. According to the patients' records, these individuals could have been infected with EBV anyway and HIV at an older age, given that they acquired HIV by sexual transmission. Therefore, HIV infection may affect the control of EBV and allow the emergence of detectable EBV ${ }^{21}$ determined that the tongue epithelial tissues of HIV-positive individuals supported not only EBV replication but also persistent, non-productive EBV infection. In immunocompromised hosts, decreased EBV-specific cytotoxic T cell activity allows increased virus replication and production in the oropharynx and latently infected circulating B cells. $^{34}$

We found an appreciable difference between the presence of EBV-1 and EBV-2 subtypes, which were responsible for $47.1 \%$ and $60 \%$ of the cases, respectively, including co-infections. Although EBV-1 is ubiquitous throughout the world, Yao et al. ${ }^{11}$ showed that the incidence of EBV type 2 is higher in HIV-positive homosexual males than in HIV-negative individuals. This study also demonstrated that most HIV patients with detectable EBV type 2 also carried the type 1 strain. In the present study, among 42 patients carrying EBV-2 DNA, only $23.8 \%$ were infected with both types. However, we could not genotype five smears because the nested PCR results were negative. The EBNA2 gene region can harbor polymorphisms. ${ }^{35}$ To determine whether polymorphisms account for our failure to type these five samples, another technique, such as sequencing, should be utilized.

We did not identify any demographic differences among HIV-EBV carriers. He et al., ${ }^{36}$ also did not find any associations with demographic factors, EBV antibodies and HIV infection despite the fact that some malignant
EBV-associated diseases are linked to racial characteristics. ${ }^{37}$ However, other studies have not found such associations. ${ }^{38}$

Furthermore, neither HIV viral load nor antiretroviral therapy affected the detection of EBV. Notably, immune status was significantly correlated with EBV and the EBV-1 genotype. Moderate or severe immune-depression modulates EBV infection. EBV and other herpes viruses are frequently found in HIV-positive individuals who have CD 4 counts lower than 200 cells $/ \mathrm{mm}^{3}{ }^{39}$ In our study, the EBV-1subtype alone was significantly associated with poor immune status. Maybe the breakdown between CD4+ cell counts and EBV-1 favors the active replication of EBV-1 more efficiently than EBV-2. In a study of HIV patients with hairy leukoplakia, Palefsky et al., ${ }^{40}$ found that $63 \%$ of patients were infected with the type 1 strain and $37 \%$ were infected with both EBV subtypes. Interestingly, the EBV-2 strain was detected in patients irrespective of their immune status, although there was a slight trend for CD4 counts lower than 500 cells $/ \mathrm{mm}^{3}$. Notably, subtype 2 enters the lytic cycle more readily than subtype 1 does. ${ }^{41}$

Sexual lifestyle was a significant risk factor for the presence of the EBV-2 subtype. We still have no explanation for this finding because the sexual transmission of EBV is a controversial topic. Some studies describe a connection between sexual behavior and EBV infection, ${ }^{42}$ whereas others demonstrate that sexual transmission of EBV has not been sufficiently established. ${ }^{43}$ Some studies report a link between increased sexual activity and the risk of type 2 detection. ${ }^{8}$ In homosexual men, the prevalence of EBV-2 is associated with a large number of sexual partners. ${ }^{10}$ And since the virus can also be transmitted by kissing, it is difficult to determine the means of infection among sexual partners. Therefore, these data could be misinterpreted. Ammatuna et al. ${ }^{13}$ found that men had an increased rate of EBV infection, but our results did not confirm any linkage between gender and EBV status despite the fact that our participants acquired HIV infection by the sexual route and that the majority of the men in our study reported homosexual behavior (data not shown). Although EBV-2 was prevalent in our study, this subtype was found equally in men and women ( $p>0.999$ ). According to these data, we do not agree with the statement that homosexual males have a higher probability of harboring the EBV-2 virus.

Among the EBV-positive HIV patients without productive lesions, $45.7 \%$ expressed the EBNA-2 messenger RNA in the oral cavity. Both subtypes expressed mRNA at the same frequencies. Differences in the transforming 
capacities of EBV subtypes 1 and 2 strains have been ascribed to differences in the EBNA- 2 gene. ${ }^{44}$ Oral hairy leukoplakia (a marker for decreased immune cell counts in HIV carriers) is the only epithelial disease in which EBNA2 is expressed, yet the role of EBNA-2 in this disease is not clear. ${ }^{21}$ EBNA-2 detection in oral epithelial tissues is not affected by immune status but is strongly associated with HIV viral load. Miller et al. ${ }^{39}$ concluded that increased EBV viral loads are dependent upon increasing HIV loads. Moreover, EBV is an important coinfection in AIDS patients and may contribute significantly to morbidity and mortality in this population. ${ }^{45}$

Some authors have suggested that there is an interaction between EBV and HIV in the regulation of replication. ${ }^{46}$ However, the mechanism of this regulation was not fully investigated. Our findings demonstrate an association between EBV activity and increased HIV loads. It is common sense that HIV loads can be linked to decreased CD 4 counts. Therefore, the role of moderate/severe immunodeficiency in affecting EBV infection is likely to be dependent upon the presence of HIV. This analysis truly strengthens the evidence for an HIV-EBV interaction.

The strong association between a detectable HIV viral load and EBNA-2 messenger RNA reflects the interaction between both viruses. Being the threshold of detection of HIV RNA 50 copies/mL, we suppose that few viruses are needed to initiate EBV activity, leading to oral lesions that include benign diseases as well as lymphomas. Routine monitoring of HIV viral loads and CD4 counts and adequate therapy may allow the containment of EBV as a self-limiting infection. This study provides guidance for monitoring HIV-infected patients with EBV reactivation in order to prevent future diseases and reduce healthcare costs. We also provide data that increases the understanding of active asymptomatic EBV infection and supports forthcoming studies of opportunistic infections in general.

\section{Conclusion}

In conclusion, our study detected a high prevalence of active EBV infection in the oral mucosa of asymptomatic HIV-infected patients, nearly half of whom exhibited EBNA-2 gene expression. The expression of EBNA-2 in the oral cavity has been identified as an important co-factor in hairy leukoplakia ${ }^{21}$ and is an indication of productive replication in the oral epithelium. Thus, it is a prognostic marker for disease development.

This work has some limitations. In the five patients for whom the subtype could not be identified, we did not perform sequencing because it was beyond the scope of our study. In spite of the fact that HIV positive persons are commonly positive to EBV, the EBV seropositivity was not tested, in order to distinguish between persons carrying latent EBV with detectable EBV DNA (with or without EBNA-2 expression) and those with latent EBV without detectable viral DNA in the mucosa. However, the seropositive status data was not meaningful for the aim of this study. Mixed infections could be underestimated by nested PCR due to differences in the viral loads for each subtype. In a larger study, with an increased number of participants, the impact of some co-factors would likely be stronger.

\section{Acknowledgements}

This work was supported by the PROPP-UFF (Pró-Reitoria de Pesquisa e Pós-Graduação da Universidade Federal Fluminense), the CNPq (Conselho Nacional de Desenvolvimento Cientifico e Tecnológico) and the FAPERJ (Fundação de Amparo à Pesquisa do Estado do Rio de Janeiro).

\section{Resumo}

Vírus Epstein-Barr na mucosa oral de pacientes positivos para o vírus da imunodeficiência humana

Objetivo: a taxa de detecção do vírus Epstein-Barr (EBV) é alta em pacientes vivendo com o vírus da imunodeficiência humana. Com o objetivo de contribuir para o entendimento epidemiológico e investigar a atividade do EBV na mucosa oral, foi realizado um estudo de coorte com pacientes HIV positivos.

Métodos: esfregaços orais de 145 pacientes HIV positivos foram coletados entre março de 2010 e março de 2011. A reação de cadeia de polimerase (PCR) internalizada e a PCR reversa (RT-PCR) foram usadas para genotipar o EBV e detectar a expressão do EBNA-2, respectivamente.

Resultados: o DNA do EBV foi detectado em 48,3\% dos participantes, dos quais $32,85 \%$ eram portadores do EBV-1 e 45,71\% de EBV-2. Adicionalmente, 14,28\% eram co-infectados por ambos os tipos. O mRNA do gene EBNA-2 foi expresso em $45,7 \%$ das amostras positivas para EBV, incluindo $20 \%$ por EBV-1 somente, $20 \%$ por EBV-2 somente e $1,4 \%$ por ambos os genótipos. O estado imune afetou a infecção por EBV, e a positividade para EBV-2 foi significativamente correlacionada com o comportamento sexual dos participantes. A co-infecção por ambos os genótipos de EBV foi dependente da carga viral de HIV e da atividade do gene EBNA-2. 
Conclusão: registrou-se uma alta prevalência de EBV em atividade na mucosa oral de indivíduos assintomáticos soropositivos para HIV. O estudo focaliza a necessidade de monitoramento e tratamento de pacientes infectados por HIV com reativação pelo EBV.

\section{Unitermos: vírus Epstein-Barr; HIV; genótipos; mucosa oral.}

\section{References}

1. Liu CD, Chen YL, Min YL, Zhao B, Cheng CP, Kang MS et al. The nuclear chaperone nucleophosmin escorts an Epstein-Barr virus nuclear antigen to establish transcriptional cascades for latent infection in human B cells. Plos Pathog. 2012;8(12):e1003084.

2. Bornkamm GW, Hammerschmidt W. Molecular virology of Epstein-Barr virus. Philos Trans R Soc Lond B Biol Sci. 2001;356:437-59.

3. Sample J, Young L, Martin B, Chatman T, Kieff E, Rickinson A et al. EpsteinBarr virus types 1 and 2 differ in their EBNA-3A, EBNA-3B, and EBNA-3C genes. J Virol. 1990; 64:4084-92.

4. Kunimoto M, Tamura S, Tabata T, Yoshie O. One-step typing of EpsteinBarr virus by polymerase chain reaction: predominance of type 1 virus in Japan. J Gen Virol. 1992;73;455-61.

5. Robaina TF, Valladares CP, Tavares DS, Napolitano WC, Silva LE, Dias EP et al. Polymerase chain reaction genotyping of Epstein-Barr virus in scraping samples of the tongue lateral border in HIV-1 seropositive patients. Mem Inst Oswaldo Cruz. 2008; 103:326-31.

6. Young LS, Yao QY, Rooney CM, Sculley TB, Moss DJ, Rupani H et al. New type B isolates of Epstein-Barr virus from Burkitt's lymphoma and from normal individuals in endemic areas. J Gen Virol. 1987;68:2853-62.

7. Figueira-Silva CM, Pereira FEL. Prevalence of Epstein-Barr virus antibodies in healthy children and adolescents in Vitória, state of Espírito Santo, Brazil. Rev Soc Bras Med Trop. 2004;37:409-12.

8. Higgins CD, Swerdlow AJ, Macsween KF, Harrison N, Williams H, McAulay $\mathrm{K}$ et al. A study of risk factors for acquisition of Epstein-Barr virus and its subtypes. J Infect Dis 2007;195:474-82.

9. Scully C, Porter SR, Di Albert, Jalal M. Maitland N. Detection of EpsteinBarr virus in oral scrapes in HIV infection, in hairy leukoplakia, and in healthy non-HIV-infected people. J Oral Pathol Med. 1998;27:480-82.

10. Van Baarle D, Hovenkamp E, Dukers NH, Renwick N, Kersten MJ, Goudsmit $\mathrm{J}$ et al. High prevalence of Epstein-Barr virus type 2 among homosexual men is caused by sexual transmission. J Infect Dis. 2000;181:2045-49.

11. Yao QY, Rickinson AB, Epstein MA. A re-examination of the Epstein-Barr virus carrier state in healthy seropositive individuals. Int J Cancer. 1985;35:3542 .

12. Amornthatree K, Sriplung H, Mitarnum W, Nittayananta W. Effects of longterm use of antiretroviral therapy on the prevalence of oral Epstein-Barr virus. J Oral Pathol Med. 2012;41:249-54.

13. Ammatuna P, Campisi G, Giovanelli L, Giambelluca D, Alaimo C, Mancuso $\mathrm{S}$ et al. Presence of Epstein-Barr virus, cytomegalovirus and human papillomavirus in normal oral mucosa of HIV-infected and renal transplanted patients. Oral Dis. 2001;7:34-40.

14. Mao EJ, Smith CJ. Detection of Epstein-Barr virus (EBV) DNA by the polymerase chain reaction (PCR) in oral smears from healthy individuals and patients with squamous cell carcinoma. J Oral Pathol Med. 1993;22:127.

15. Cruz I, Van den Brule AJ, Steenbergen RD, Snijders PJ, Meijer CJ, Walboomers JM. Prevalence of Epstein-Barr virus in oral squamous cell carcinomas, premalignant lesions and normal mucosa - a study using the polymerase chain reaction. Oral Oncol. 1997;33:182-8.

16. Sand LP, Jalaouli J, Larsson PA, Hirsch JM. Prevalence of Epstein-Barr virus in oral squamous cell carcinoma, oral lichen planus, and normal oral mucosa. Oral Surg Oral Med Pathol Oral Radiol Endod. 2002;93:586-92.

17. Strowig T, Brilot F, Arrey F, Bougras G, Thomas D, Muller WA, Mun C. Tonsilar NK cells restrict B cell transformation by the Epstein-Barr virus via IFN-gamma. PLoS Pathog. 2008;4:e27.

18. Carbone A, Cesarman E, Spina M, Gloghini A, Schulz TF. HIV-associated lymphomas and gamma-herpesviruses. Virus Res. 2009;143:209-21.
19. Vetsika EK, Callan M. Infectious mononucleosis and Epstein-Barr Virus. Expert Rev Mol Med. 2004;6:1-16

20. Kempkes B. EBNA-2 in transcription activation of viral and cellular genes. In: Robertson ES, editor. Epstein-Barr virus: latency and transformation. Pennsylvania: Caister Academic Press; 2010

21. Walling MD, Ling PD, Gordadze AV, Montes-Walters M, Flaitz CM, Nichols CM. Expression of Epstein-Barr virus latent genes in oral epithelium: determinants of the pathogenesis. J Infect Dis. 2004;190:396-9.

22. Webster-Cyriaque J, Raab-Traub N. Transcription of Epstein-Barr virus latent cycle genes in oral hairy leukoplakia. Virology. 1998;248:53-65.

23. Hernádi K, Szalmás A, Mogyorósi R, Czompa L, Veress G, Csoma E et al Prevalence and activity of Epstein-Barr virus and human cytomegalovirus in symptomatic and asymptomatic apical periodontitis lesions. J Endod. 2010;36:1485-9.

24. Maier S, Staffler G, Hartmann A, Höck J, Henning K, Grabusic K et al. Cellular target genes of Epstein-Barr virus nuclear antigen 2. J Virol. 2006;80:9761-71

25. Health Ministry. AIDS Program. In: Health Ministry, STD, AIDS and viral hepatitis program 2011. [cited 2012 jan 8]. Available from:http://www.aids. program.

26. Durmaz R, Aydin A, Köroglu M, Aker H, Ozercan IH, Atik E et al. Detection and genotyping of Epstein-Barr virus by polymerase chain reaction in tissues obtained from cases with Hodgkin's disease in Turkey. Acta Virol. 1998;42:375-81.

27. Telenti A. PCR detection and typing of Epstein-Barr virus. In: Persing DH, Smith TF, Tenover FC, White TJ. Diagnostic molecular microbiology. Washington (DC): American Society for Microbiology; 1993. p.344-9.

28. Carvalho KS, Silvestre EA, Maciel SS, Lira HI, Galvão RA, Soares MJ et al. PCR detection of multiple human herpesvirus DNA in saliva from HIVinfected individuals in Teresina, State of Piauí, Brazil. Rev Soc Bras Med Trop. 2010;43:620-3.

29. Gulley ML, Tang W. Using Epstein-Barr viral load assays to diagnose, monitor, and prevent posttransplant lymphoproliferative disorder. Clin Microbiol Rev. 2010;23:350-66.

30. Steven NM. Epstein-Barr virus latent infection in vivo. Rev Med Virol. 2008;7:97-106

31. Maurmann S, Fricke L, Wagner HJ, Schlenke P, Hennig H, Steinhoff J et al. Molecular parameters for precise diagnosis of asymptomatic Epstein-Barr virus reactivation in healthy carriers. J Clin Microbiol. 2003;41:5419-28.

32. Yao QY, Croom-Carter DS, Tierney RJ, Habeshaw G, Wilde JT, Hill FG et al. Epidemiology of infection with Epstein-Barr virus types 1 and 2: lessons from the study of a T-cell-immunocompromised hemophilic cohort. J Virol. 1998;72:4352-63

33. Herrmann K, Frangou P, Middeldorp J, Niedobitek G. Epstein-Barr virus replication in tongue epithelial cells. J Gen Virol. 2002;83:2995-8.

34. Haque T, Thomas JA, Parratt R, Hunk BJ, Yacoub MH, Crawford DA. A prospective study in heart and lung transplant recipients correlation persistent Epstein-Barr virus infection with clinical events. Transplantation. 1977;64:1028-34.

35. Sheng W, Bouguermouh A, Bouzid M, Djennaoui D, Ooka T. BAMHI DNA fragment $\mathrm{H}$-polymorphism of Epstein-Barr virus is associated with the mutations present in an $89 \mathrm{BP}$ sequence localized in EBNA2 gene. Virus Genes. 2004;29:99-108.

36. He N, Chen L, Lin HJ, Zhang M, Wei J, Yang JH et al. Multiple viral coinfections among HIV/AIDS patients in China. Biosci Trends. 2011;5:1-9.

37. Flavell KJ, Biddulph JP, Powell JE, Parkes SE, Redfern D, Weinreb M et al. South Asian ethnicity and material deprivation increase the risk of Epstein-Barr virus infection in childhood Hodgkin's disease. Br J Cancer. 2001;85: 350-6.

38. Boulter A, Johnson NW, Birnbaum W, Johnson NW, Teo CG. Epstein-Barr virus (EBV) associated lesions of the head and neck. Oral Dis. 1996;2:117-24

39. Miller CS, Berger JR, Mootoor Y, Avdiushko SA, Zhu H, Kryscio RJ. High prevalence of multiple human herpesviruses in saliva from human immunodeficiency virus-infected persons in the era of highly active antiretroviral therapy. J Clin Microbiol. 2006; 44:2409-15.

40. Palefsky JM, Berline J, Greenspan D, Greenspan JS. Evidence for trafficking of Epstein barr virus strains between hairy leukoplakia and peripheral blood linphocytes. J Gen Virol. 2002;83:317-21.

41. Buck M, Cross S, Krauer K, Kienzle N, Sculley TB. A-type and B-type EpsteinBarr virus differ in their ability to spontaneously enter the lytic cycle. J Gen Virol. 1999;80:441-5.

42. Woodman CBJ, Collins SI, Vavrusova N. Role of sexual behavior in the acquisition of asymptomatic Epstein-Barr virus infection. A longitudinal study. Pediatr Infect Dis J. 2005;24:498-502. 
43. Kantakamalakul W, Naksawat P, Kanyok R, Puthavathana P, Thomas $\mathrm{R}$, Reid $\mathrm{S}$ et al. Prevalence of type specific Epstein-Barr virus in the genital tract of genital herpes suspected patients. J Med Assoc Thai. 1999;82:263-6.

44. Cohen JI, Wang F, Mannick J, Kieff E. Epstein-Barr virus nuclear protein 2 is a key determinant of lymphocyte transformation. Proc Natl Acad Sci U S A. 1989;86:9558-62.
45. Mujtaba S, Varma S, Sehgal S. Coinfection with Epstein Barr virus in North Indian patients with HIV/AIDS. Indian J Pathol Microbiol. 2005;48:349-55.

46. Mbopi-Kéou FX, Bélec L, Teo CG, Scully C, Porter SR. Synergism between HIV and other viruses in the mouth. Lancet Infect. Dis. 2002;2:416-24.

47. Gulley ML. Molecular diagnosis of Epstein-Barr virus-related diseases. J Mol Diagn. 2001;3:1-10. 